\title{
A systematic review to explore influences on parental attitudes towards antibiotic prescribing in children
}

\author{
Helen Bosley, Catherine Henshall, Jane V. Appleton, Debra Jackson
}

\section{Correspondence to: Helen Bosley email: 15129061@brookes.ac.uk}

\section{Authors:}

\section{Helen Bosley}

Doctoral Researcher, BSc (Hons) RGN, RSCN

Oxford Institute of Nursing, Midwifery \& Allied Health Research (OxINMAHR)

Faculty of Health \& Life Sciences, Oxford Brookes University, UK.

\section{Catherine Henshall,}

Senior Nursing Research Fellow, MN, RGN, MA, PhD

Oxford Institute of Nursing, Midwifery \& Allied Health Research (OxINMAHR)

Faculty of Health \& Life Sciences, Oxford Brookes University and NIHR Oxford cognitive health Clinical Research Facility, Oxford Health NHS Foundation Trust, UK.

\section{Jane V. Appleton}

Professor, BA (Hons), RGN, RHV, MSc, PGCEA, PhD, FiHV

Professor of Primary and Community Care,

Oxford Institute of Nursing, Midwifery \& Allied Health Research (OxINMAHR)

Faculty of Health \& Life Sciences, Oxford Brookes University, UK.

\section{Debra Jackson}

Professor, PhD FACN

Professor of Nursing and Director, Oxford Institute of Nursing, Midwifery \& Allied Health Research (OxINMAHR), Faculty of Health \& Life Sciences, Oxford Brookes University, UK. Professor of Nursing, University of Technology, Sydney (UTS), Australia. 


\title{
A systematic review to explore influences on parental attitudes towards antibiotic prescribing in children
}

\begin{abstract}
Title: A systematic review to explore influences on parental attitudes towards antibiotic prescribing in children.

Aim: To understand the factors influencing parental attitudes towards antibiotic prescribing.

Background: Overuse of antibiotics and inappropriate prescribing has resulted in rapid development of antimicrobial resistance (AMR), and is significant global threat to patient safety. In Primary Care settings, substantial numbers of antibiotics are prescribed for young children, despite viral nature of illness for which antibiotics are ineffective. Parents, play a vital role in decision making regarding accessing healthcare services and requesting treatment for their children.
\end{abstract}

Design: A systematic review was conducted in alignment with the Preferred Reporting Items for Systematic Reviews and Meta-analyses (PRISMA) statement (Moher et al 2015).

Methods: The CINAHL, MEDLINE, PsycINFO, The Cochrane Library, BRITISH NURSING INDEX, EMBASE and PUBMED databases were searched for primary research published between 2006-16. All types of primary research were searched and screened against inclusion criteria. The Critical Appraisal Skills Programme tool was used to appraise identified publications. Quantitative data was summarised descriptively and qualitative data was thematically analysed.

Results: A total of 515 publications were initially screened, and 55 full-text articles were eligibility assessed. Twenty papers met inclusion criteria. Four main themes were identified: the quality of relationships with health care providers, dealing with conflicting messages, rationalising antibiotic use and parental practices informed by past experience.

Conclusion: Parents wanted reassurance and advice regarding children's illnesses, had poor antibiotic knowledge and were influenced by personal past experiences. More accessible education, including simple information leaflets, is required. Further research on the influence of culture, ethnicity and socio- economic factors would be beneficial.

Search terms: parent, maternal, beliefs, attitudes, antibiotics, child, primary care.

Relevance to clinical practice: Health care professionals must provide adequate time for reassurance and explanations of decision making. Easy to read information regarding appropriate antibiotic usage should be easily accessible for parents. 


\section{What does this paper contribute to the wider global clinical community?}

- $\quad$ This review identified the lack of parental knowledge regarding proper use of antibiotics. More information needs to be provided to parents and the wider community to ensure decision making is informed and appropriate.

- It highlights the importance of the relationship between clinicians and parents in managing children's illness. Parents trust and rely on the clinician to provide information and reassurance on their child's health. Clinicians need to recognise and develop the relationship to support parental expectations

\section{INTRODUCTION}

The use of antibiotics is a core and integrated component in modern healthcare (Department of Health 2013; Chief Medical Officer Report 2011).However, the global, widespread use of antibiotics in healthcare, animal health and food production, has led to a serious overuse and abuse of antibiotics. As a result, there has been an emergence of a phenomenon called antimicrobial resistance (AMR); defined as a microorganism's resistance to an antimicrobial drug to which it was once effective (World Health Organisation 2016). AMR is developing faster than new strains of antibiotics are being developed. Very few new antibiotics have reached the market in the last 30 years, (Parliamentary Science and Technology Committee 2014) primarily due to difficulties demonstrating their efficacy or because of unacceptable side effects such as nausea and vomiting. In addition, the poor financial return associated with antibiotic development and licensing does little to incentivise pharmaceutical companies to focus their resources on this activity (Sukkar 2013).

AMR is considered to be one of the most significant threats to patient safety worldwide (HM Government 2016, Johnstone 2016). Resistance to antibiotics makes procedures such as minor surgery and routine operations high-risk, increasing the duration of illness and leading to premature mortality (Chief Medical Officer Report 2011; HM Government 2016). A review on AMR published in 2016 found that currently 700,000 people die each year due to resistant infections and it is estimated that by 2050 the world will face an additional 10 million deaths due to AMR infections at a cost of $\$ 100$ trillion to the global economy (HM Government 2016).

In response to the threat of AMR, the UK government has published the Five Year Antimicrobial Resistance Strategy 2013 to 2018 (Department of Health 2013). This strategy includes key actions to improve the knowledge and understanding of AMR, including the provision of better information for the general public, improved global surveillance of drug resistance and antimicrobial consumption in humans and animals, and the development of more effective early warning systems to improve health outcomes. The strategy also sets out to conserve and steward the effectiveness of existing antibiotic treatments and stimulate the development of new ones (Department of Health 2013). Research indicates doctors are the primary prescribers of antibiotics in the community and prescribe more often than clinically necessary. A substantial number of patients fail to complete a full course of antibiotics, as their symptoms improve, sometimes saving tablets for later self-medication (McNulty et al 2013). Failure to complete a course of antibiotics could allow microorganisms to recover and develop resistance to the 
antibiotic, affecting future efficacy (Davies and Davies 2010). In addition, some patients believe that antibiotics are effective against viruses (McNulty et al 2007), and some evidence from the Parliamentary Science and Technology Committee (2014), indicates considerable pressure from patients on clinicians to prescribe antibiotics, as well as poor public awareness of AMR and the potential risks associated with increasing AMR.

In 2015, Public Health England (PHE) published the second annual report from the English Surveillance Programme for Antimicrobial Utilisation and Resistance (ESPAUR), which showed that, in 2014, the majority of antibiotics in England were prescribed in general practice (74\%). Total antibiotic prescribing, which is measured using defined daily doses (DDD), a standardised measure of antibiotic consumption, continues to increase in the National Health Service (NHS) by 6.2\% (16.1 to 17.1 DDD per 1000 inhabitants) between 2011 and 2014 and 2.1\% between 2013 and 2014. However, this increase was at a slower rate in 2013-2014. The total number of prescriptions dispensed has decreased, whilst total antibiotic consumption in primary care has increased. This suggests higher doses or longer course lengths in general practice prescriptions.

Antibiotics are prescribed in about one in five general practitioner (GP) consultations, with about $25 \%$ being prescribed to children between the ages of one and fourteen years (Murphy et al 2012). However, most childhood illnesses are caused by viruses rather than bacteria (Murphy et al 2012) often spontaneously resolving without medical intervention, as in the case of the common cold or in childhood illnesses such as chickenpox. Clinicians report parents' apply pressure for antibiotics to be prescribed, mostly on behalf of their children (Stivers 2002). However, inappropriate prescribing of antibiotics by clinicians can reinforce the belief that antibiotics ought to be prescribed and are effective in circumstances when they are not (Mangione-Smith et al 2006). Therefore, the need to educate both clinicians and parents, as the primary care givers, regarding the appropriate use of antibiotics is vital in safeguarding existing, effective antibiotics for the future.

\section{Aim and research questions}

The aim of the review was to examine the literature to explore any influences on parental attitudes to antibiotic prescribing and aimed to answer the following research questions:

- What factors influence parental attitudes and expectations in relation to antibiotic prescribing for their children; and,

- To what extent do social factors such as parental age, socio-economic groups, ethnicity, family cultures, beliefs and cultural background, influence parental attitudes.

\section{METHODS}

\section{Design}

A systematic approach to literature searching was used. The CINAHL, MEDLINE, PsycINFO, The Cochrane Library, BRITISH NURSING INDEX, EMBASE and PUBMED databases were searched for primary research published between 2006-16, relating to the research question and using the identified search terms: parent, mother, maternal, beliefs, attitudes, antibiotics, child, primary care, general practice viral illness.

\section{Search methods}

The review included all relevant published research conducted worldwide between the years 2006-2016 exploring knowledge, attitudes and practices of parents regarding use of antibiotics in 
primary care for their children. Searches were limited to the last ten years due to significant changes and increased recognition of the risk of antibiotic overuse in this time. Studies before this may not reflect current practices or knowledge. All publications, including cohort studies, randomised controlled trials (RCTs), and both observational studies and qualitative studies were eligible. Only primary research studies which were published in English were eligible for inclusion. Grey literature was searched and included Department of Health, World Health Organisation, HM Government, Centre for Disease Control, Royal Pharmaceutical Society, Royal College of General Practitioners and Public Health England literature. Additional searches were conducted using Google Scholar to identify any other relevant or unpublished studies. An additional hand search was conducted of the identified article references to ensure relevant studies were not missed and maximum relevant articles were obtained (Aveyard 2014).

\section{Eligibility Criteria Inclusion criteria}

All global studies published in English, conducted in the last 10 years and directly exploring the knowledge, attitudes and practices of parents towards antibiotic prescribing in children were included in the review.

\section{Exclusion criteria}

Exclusion criteria included primary research relating to doctors or GP's or prescribers attitudes to antibiotic prescribing, studies not published in English language, non primary research, and publications pre 2006.

\section{Search outcome}

\section{Selection of studies}

A total of 515 articles were identified for initial review. Titles and abstracts were screened for eligibility, inclusion and exclusion criteria applied and any duplicate articles identified and removed. Following this process twenty articles remained (see table 1 ). In seventeen of the studies reviewed, at least half the participants were mothers and one study focussed solely on mothers (Alkhaldi et al 2015). One study had more participants who were fathers than mothers (Alili-Idrizi et al 2014). Two studies did not distinguish between mothers or fathers (Cabral et al 2016; Salazar et al 2012).

\section{Quality appraisal}

The quality of the publications was assessed by the first author and cross checked by another member of the research team, using the Critical Appraisal Skills Programme (CASP) tool. The twenty studies were reviewed for validity, credibility, and relevance to the research question. Any ethical considerations, the recruitment strategies used, data analysis methods and the studies contribution to current knowledge were also assessed. This information was shared with the research team to ensure verification and satisfaction with the quality appraisal process. The predominant methodology (16 studies) was quantitative, using surveys and questionnaires. There is a risk of recall bias as reliant on parental recall accuracy of experiences (Sackett 1979).The bias in two qualitative studies was low and the remaining qualitative and mixed methods were unclear.

A summary of the articles included in the review can be found in table 2 . 


\section{Data abstraction}

The selected research papers were reviewed by the first author to determine what factors influenced parental attitudes and decision making, regarding expectations for antibiotic prescribing for their children. The findings were then discussed and shared with the research team in regular team meetings. This provided the opportunity to address any uncertainties relating to the data extraction process. It was not necessary to contact any authors of included studies during the review for missing information.

\section{Risk of bias}

There was a risk of recall bias in all the articles, as they all relied on participants recounting previous experiences, which may have been remembered differently over time. In addition, fourteen studies recruited parents from healthcare settings where parents were waiting to see their clinician regarding the health of their child. This setting could have influenced their perception and the accuracy of answers, as parents are likely to have used antibiotics in the past and been involved in seeking support and advice from a clinician.

\section{Data synthesis}

The data from the quantitative studies was summarised as descriptive statistical data. Thematic analysis (based on Braun and Clarke 2006) was used to analyse the qualitative data findings and identify any common themes. These included the quality of relationships with health care providers, dealing with conflicting messages, rationalising the need for antibiotics and parental practices informed by past experience.

\section{RESULTS}

\section{Characteristics of the studies}

Studies, which met the criteria, were represented from across the world: Asia (6), Middle East (4), UK (3), Europe (3), USA (4) and South America (1). Parents were recruited to studies from various routes. Twelve studies recruited from parents attending a child health clinic or vaccination clinic. Six studies recruited parents, either as part of a general population survey or via schools, and two studies recruited when parents attended hospital outpatient departments with their child.

\section{Quantitative studies}

Sixteen studies used quantitative statistical analysis of survey data to identify the knowledge, attitudes and practices of parents towards antibiotic prescribing. Thirteen used surveys in a crosssectional study design to capture a descriptive snapshot of what was occurring in a population (Booth, Papaioannou and Sutton 2012).

\section{Qualitative studies}

Three studies used qualitative approaches and thematic analysis to explore through dialogue of parental attitudes. This consisted of focus groups and interviews.

\section{Mixed Methods}

One study used mixed methods and consisted of a quantitative telephone survey and qualitative focus groups. 


\section{Summary of main findings}

Thematic analysis of the papers identified four main themes from the literature review. These were 'quality of relationships with health care providers', 'dealing with conflicting messages', 'rationalising the need for antibiotics', and 'parental practices informed by past experience'(see table 3).

\section{Quality of relationships with health care providers}

Eleven of the studies identified the importance of relationship quality between parents and clinicians. These studies found parents were concerned and anxious for their child's health and wanted to be reassured regarding the decision making and care their clinicians provided (AlDossari 2013, Alili-Idrizi et al 2014, Alkhaldi et al 2015, Brookes-Howell et al 2013, Cabral et al 2016, Chinnasami et al 2016, Ecker et al 2013, Panagakou et al 2011, Rousounidis et al 2011, Salazar et al 2012, Zyoud et al 2015).

The relationship quality between the parent/clinician was founded on trust. In half the studies, trust was more likely to develop if parents experienced open communication. This involved easy clinician access, and using a range of communication methods (telephone, email, appointments) which enabled relationship building (Al-Dossari 2013, Alkhaldi et al 2015, Brookes-Howell et al 2013, , Chinnasami et al 2016, Ecker et al 2013, Finkelstein et al 2013, Panagakou, et al 2011, Rousounidis et al 2011, Vaz et al 2015, Zyoud et al 2015).

The importance of communication was identified in ten studies, which recognised parents relied on their clinicians for advice and information on their child's treatment options. This clinician engagement enabled parents to feel supported in their decision making and resulted in feelings of general satisfaction with the amount of information they were given regarding the need for antibiotics and the risks involved (Al-Dossari 2013, Alkhaldi et al 2015, Brookes-Howell et al 2013, Cabral et al 2016, Chinnasami et al 2016, Ecker et al 2013, Panagakou et al 2011, Rousounidis et al 2011, Salazar et al 2012, Zyoud et al 2015).

However, in seven studies, parents did not experience good communication with their clinicians, as they felt clinicians used complex language, did not explain the terms they used and did not spend enough time providing explanations (Agarwal et al 2015, Alkhaldi et al 2015, Cabral et al 2016, Chinnasami et al 2016, Dwibedi et al 2015, Ecker 2013, Wun et al 2012). Three studies identified a lack of time as contributing to poor explanations of the rationale for decision making and antibiotic side effect profiles (Alkhaldi et al 2015, Ecker et al 2013, Wun, et al 2012); this led to parents not understanding why treatments were being offered or when antibiotics should be used. As a result, parents felt ill-informed regarding the care of their child (Agarwal et al 2015, Al Dossari 2013, Alkhaldi et al 2015).

Eleven studies identified that in private healthcare systems, regular follow ups with clinicians either by phone or home/office visit, were more common. Parents reported more satisfaction when they knew and trusted their clinician and felt the clinician knew their family (Al-Dossari 2013, Alili-Idrizi et al 2014, Alkhaldi et al 2015, Brookes-Howell et al 2013, Cabral et al 2016, Chinnasami et al 2016, Ecker et al 2013, Panagakou et al 2011, Rousounidis et al 2011, Salazar et al 2012, Zyoud et al 2015). However, in three of the studies, parents felt that the clinician did not know their child or discuss their child's health with them, resulting in a feeling of lack of trust in the clinician and reduced compliance from parents (Alkhaldi et al, Dwibedi et al 2015, Wun et al 2012). One US study identified some parents felt clinicians were rude to them if they asked questions about their child's illness (Dwibedi et al 2015), preventing them from doing so and from interacting with healthcare professionals. 


\section{Dealing with conflicting messages}

A dominant theme, identified in the majority of the studies, was the variation in parental knowledge, attitudes and practices on antibiotic use and misuse in children with upper respiratory tract infections (URTI) (Agarwal et al 2015, Al-Dossari 2013, Alili-Idrizi et al 2014, Alkhaldi et al 2015, Brookes-Howell et al 2013, Chan and Tang 2006, Chinnasami et al 2016, Ecker et al 2013, Farha et al 2016, Finkelstein et al 2013, Panagakou et al 2011, Rousounidis et al 2011, Salazar et al 2012, Wun et al 2012, Yu et al 2014, Zyoud et al 2015). In fifteen studies, the levels of education were cited as significant to parents' knowledge (Agarwal et al 2015, Al-Dossari 2013, Alili-Idrizi et al 2014, Alkhaldi et al 2015, Chan and Tang 2006, Chinnasami et al 2016, Dwibedi et al 2015, Ecker et al 2013, Farha et al 2016, Panagakou et al 2011, Rousounidis et al 2011, Salazar et al 2012, Salonga 2009, Vaz et al 2015, Yu et al 2014). In four studies (Agarwal et al 2015, AlDossari 2013, Ecker et al 2013, Zyoud et al 2015), parents could not generally identify or name an antibiotic and only two studies cited that parents had knowledge of the importance of completing antibiotic courses (Agarwal et al 2015, Ecker et al 2013).

Four studies conducted in Asia and the Middle East respectively, identified that fathers usually had higher education levels (Agarwal et al 2015, Alkhaldi et al 2015, Alili-Idrizi et al 2014, Farha et al 2016). This may have influenced decision making in the family as the mothers were often the main carers staying at home and therefore making most of the daily decisions for the children. Several studies found that mothers with a higher level of education, increased family income and private medical insurance were less likely to expect to receive antibiotics (Al-Dossari 2013, Alkhaldi et al 2015, Dwibedi et al 2015, Farha et al 2016, Salazar et al 2012). However, in the study by Alkhaldi et al (2015) mothers with less or restricted financial income were more likely to keep left over antibiotics or purchase antibiotics from pharmacies rather than seeing their clinician.

Nine studies identified the belief that symptoms caused by viral illnesses required antibiotic treatment (Agarwal et al 2015, Alkhaldi et al 2015, Chinnasami et al 2016, Farha et al 2016, Finkelstein et al 2013, Rousounidis et al 2011, Wun et al 2012, Yu et al 2014, Zyoud et al 2015). However, six studies found parents understood that viral illnesses were self-limiting and therefore did not require treatment (Al-Dossari 2013, Alkhaldi et al 2015, Ecker et al 2013, Farha et al 2016, Panagakou et al 2011, Zyoud et al 2015).

Primary sources of information regarding antibiotics were provided by clinicians in eight studies (Al-Dossari 2013, Alkhaldi et al 2015, Panagakou et al 2011, Rousounidis et al 2011, Salazar et al 2012, Vaz et al 2015, Yu et al 2014, Zyoud et al 2015). Nine studies identified that other sources of information accessed by parents, included pharmacies, newspapers, media, internet, family and friends (Al-Dossari 2013, Alkhaldi et al 2015, Brookes-Howell et al 2013, Farha et al 2016, Panagakou et al 2011, Rousounidis et al 2011, Salazar et al 2012, Yu et al 2014, Zyoud et al 2015). A common theme found in over half the studies, was that many parents did not know about possible antibiotic side effects (Agarwal et al 2015, Al-Dossari 2013, Brookes-Howell et al 2013, Chinnasami et al 2016, Ecker et al 2013, Farha et al 2016, Rousounidis et al 2011, Salazar et al 2012, Salonga 2009, Wun et al 2012, Zyoud et al 2015), and in three studies, parents believed there were no side effects at all (Agarwal et al 2015, Salonga 2009, Wun et al 2012). Although, in over half the studies parents reported being aware of AMR, this did not seem to significantly influence their approach to using antibiotics (Alili-Idrizi et al 2014, Brookes-Howell et al 2013, Chinnasami et al 2016, Ecker et al 2013, Farha et al 2016, Finkelstein et al 2013, Panagakou et al 2011, Rousounidis et al 2011, Wun et al 2012, Yu et al 2014, Zyoud et al 2015). In a third of the studies, antibiotics were commonly seen as being effective treatments for managing upper respiratory infection (URTI) symptoms caused by viruses and were believed to 
shorten the duration of illness (Alili-Idrizi et al 2014, Alkhaldi et al 2015, Chinnasami et al 2016, Ecker et al 2013, Panagakou et al 2011, Rousoundis et al 2011, Yu et al 2014). The shortening of symptom duration was seen as important in reducing the child's illness and parental anxiety in a couple of studies (Alili-Idrizi et al 2014, Chinnasami et al 2016). Half the studies identified that parents perceived antibiotics reduced complications of viral infections such as secondary infection (Al-Dossari, 2013, Alili-Idrizi et al 2014, Alkhaldi et al 2015, Brookes-Howell et al 2013, Cabral et al 2016, Ecker et al 2013 Panagakou et al 2011, Rousounidis et al 2011, Wun et al 2012, Zyoud et al 2015).

\section{Rationalising the need for antibiotics}

Nearly three quarters of the studies identified discrepancies in the perception of parents and clinicians regarding the expectation of receiving antibiotics (Al-Dossari 2013, Alili-Idrizi et al 2014, Cabral et al 2016, Chan and Tang 2006, Chinnasami et al 2016, Farha et al 2016, Finkelstein et al 2013, Panagakou et al 2011, Rousounidis et al 2011, Salazar et al 2012, Salonga 2009, Wun et al 2012 , Yu et al 2014, Zyoud et al 2015). In one study, $28 \%$ of parents reported they directly requested antibiotics from their clinician. This was in contrast to $60 \%$ of clinicians who reported feeling directly pressurised by parents to prescribe antibiotics, which they expected to receive even when not clinically indicated (Rousounidis et al 2011).The familiarity and relationship with the clinician may have influenced mothers to ask for and receive antibiotics.

Six studies found parent's attitudes and beliefs are influenced by anxiety and concern for their child's welfare (Alkhaldi et al 2015, Brookes-Howell et al 2013, Cabral et al 2016, Dwibedi et al 2015, Ecker et al 2013, Finkelstein et al 2013). This concern resulted in seeking clinician advice. However, if the advice resulted in antibiotic prescribing, the perception of the seriousness of the child's illness and antibiotic need was reinforced (Alili-Idrizi et al 2014, Rousoundis et al 2011). Two other studies identified that if a child had received antibiotics in the past for a similar illness, parents expected an antibiotic prescription would be provided again. When parents did receive antibiotics it reinforced belief in their decision making (Cabral et al 2016, Ecker et al 2013). Three studies cited the rationalising of antibiotic usage to prevent child illness (Al-Dossari 2013, Alkhaldi et al 2015, Yu et al 2014). In one study, nearly half of parents believed antibiotics could protect children from common colds and therefore they were more likely to give antibiotics prophylactically (Yu et al 2014). Only two studies identified that parents recognised antibiotics should be kept for more serious illnesses (Cabral et al 2016, Chan and Tang 2006). Six studies identified that parents believed antibiotics could treat all manner of infections, were considered 'wonder' drugs and in limitless supply as new antibiotics were always being developed (Chan and Tang 2006, Ecker et al 2013, Panagakou et al 2011, Rousoundis et al 2011,Yu et al 2014, Zyoud et al 2015). The culture of parents, which includes the ideas, customs, and social behaviour, was identified in five studies to influence antibiotic usage (Alkhaldi et al 2015, Chan and Tang 2006, Panagakou et al 2011, Salazar et al 2012, Salonga 2009).

\section{Parental practices informed by past experience}

Over half the studies explored antibiotic prescribing in relation to upper respiratory tract infections (Al-Dossari 2013, Alkhaldi et al 2015, Brookes-Howell et al 2013, Cabral et al 2016, Chan and Tang 2006, Farha et al 2016, Panagakou et al 2011, Rousounidis et al 2011, Salonga 2009, Wun et al 2012, Zyoud et al 2015). Parents were found to base their practices on what had worked previously when their child had presented with similar symptoms. Parents wanted to relieve symptoms of pain and discomfort for their child and nearly half of parents expected and received antibiotics for ear pain, fever and sore throats (Al-Dossari 2014). 
The purchase of over the counter antibiotics was identified in over half the studies as being common practice by parents (Al-Dossari 2013, Alkhaldi et al 2015, Chan and Tang 2006,

Chinnasami et al 2016, Ecker et al 2013, Farha et al 2016, Rousounidis et al 2011, Salonga 2009, Yu et al 2014, Zyoud et al 2015). Four studies identified this practice was primarily associated with the easy access and availability of antibiotics without a clinician prescription (Al-Dossari 2013, Ecker et al 2013, Farha et al 2016, Yu et al 2014). One study identified that parents felt antibiotics reduced their anxiety and were more convenient for them, primarily because time was not spent visiting clinicians for an initial review (Al-Dossari 2013).

Six studies found parents used leftover antibiotics to treat their children (Al-Dossari 2013, Chan and Tang 2006, Farha et al 2016, Salonga 2009, Yu et al 2014, Zyoud et al 2015). This practice was influenced by personal past experience in seven studies. When children had previously received antibiotics for a similar infection, parents relied on this experience to manage the new illness (Agarwal et al 2015, Alkhaldi et al 2015, Ecker et al 2013, Farha et al 2016, Panagakou et al 2011, Zyoud et al 2015). However, in over a quarter of the studies parents did not finish the antibiotic course for their children (Al-Dossari 2013, Alkhaldi et al 2015, Chan and Tang 2006, Chinnasami et al 2016, Ecker et al 2013, Yu et al 2014). This was largely due to an improvement in the child's symptoms (Chan and Tang 2006, Yu et al 2014), although three studies cited antibiotic cost as a reason (Alkhaldi et al 2015, Finkelstein et al 2013, Salazar et al 2012). The majority of the studies identified antibiotic prescriptions as the primary treatment for managing illness. However, two studies cited parents would use home remedies to initially treat common viral symptoms of pyrexia, pain and coughs (Brookes-Howell et al 2013, Finkelstein et al 2013).

\section{DISCUSSION}

The review findings identified some common themes, which influenced parental expectations regarding antibiotic prescribing. A major influence was the anxiety and concern experienced by parents about their child's health and the relationship with the clinician. Parents trusted their clinician to care for their child, which included a thorough physical assessment and appropriate treatment. This resulted in them seeking reassurance, including a medical review. The concern for their child meant that parents often consulted clinicians promptly within the first two days of illness (Panagakou et al 2011). This behaviour seemed to be primarily due to anxiety and concern rather than any public health messages regarding when to visit the clinician. The consultation was to gain reassurance, validate decision making and to be seen as a good parent (Ecker et al 2013, Panagakou et al 2011). In a study by Ecker et al (2013), visiting a clinician and gaining reassurance was preferred by parents to purchasing antibiotics which were readily available. However, antibiotics were often considered to be the correct treatment. This could be due to the perception antibiotics were 'wonder' drugs, which could treat any illness (Chan and Tang 2006, Ecker et al 2013, Panagakou et al 2011, Rousounidis et al 2011, Yu et al 2014, Zyoud et al 2015). This belief and perception of antibiotic usage was likely to be influenced by the amount of knowledge parents possessed.

The literature review identified there was a large variation in the nature and quality of information and communication from clinicians, experienced by parents. Clinicians were the main source of information for parents regarding antibiotic usage and parents wanted to be informed about appropriate prescribing, risks and side effects and implications for use. However, the literature identified that parents reported clinicians used complex words and jargonistic language, which meant they did not understand the information provided. They also felt clinicians did not spend enough time explaining the treatment decision making. This meant that parents felt their clinician did not know their child and resulted in a lack of trust and poor level of knowledge 
regarding antibiotic usage. A poor relationship may influence parents not to seek medical intervention, but source alternatives such as self-prescribing antibiotics. Clinicians need to prioritise sufficient appointment time for clinical review. Use of simple terms and adequate explanations, ensuring the parents have the opportunity to ask questions will reassure parents. This may impact the expectations and perceptions of the child's illness and influence future parental behaviour.

The link between education and knowledge was another clear finding in the review. Parents in less developed countries demonstrated significantly lower levels of knowledge in comparison ( $\mathrm{Yu}$ et al 2014) with Western countries (Cabral et al 2016). The literature suggested this was linked to the level of education received by the parent, as parents with basic education were not as well informed regarding use and impact of antibiotics, as parents with higher education levels. This was reflected in a study conducted by Yu et al (2014) into the knowledge, attitudes, and practices of parents in rural China on the use of antibiotics in children. In this study parents in rural areas were much less knowledgeable about antibiotics than parents living in towns or urban areas. This may reflect that only $5 \%$ of parents in rural areas had experienced education at college level or above, compared to $39 \%$ of parents in urban areas. The difference in education may influence the exposure and familiarity with access to internet resources and other sources of information. The difference between lower education levels and increased misconceptions about antibiotic usage was also identified by Salonga (2009). However, this study identified antibiotic self-prescribing was more common in parents with higher levels of educational attainment. There is no clear indication for this, however it is possible parents with high education levels may perceive themselves to be well informed and therefore more confident about appropriate antibiotic usage. The literature identified another important predictor of decreased knowledge of antibiotic usage was the age of the parents, with younger parents having less knowledge (Vaz et al 2015). This may be due to the fact that young parents have not had as much parenting practice and therefore caring for an ill child is a new experience. To support parents, readily accessible information and knowledge needs to be provided by healthcare professionals. The information needs to be simple and easy to understand, regarding management of common childhood illnesses and when to use antibiotics, and could be made available as leaflets and posters.

The influence of anxiety for the child on parents' attitudes and beliefs was another identified theme (Alkhaldi et al 2015, Brookes-Howell et al 2013, Cabral et al 2016, Dwibedi et al 2015, Ecker et al 2013, Finkelstein et al 2013). Parents were concerned they will misinterpret and not recognise the symptoms of serious illnesses, which may lead to dangerous deterioration in their child's condition. This may be due to the lack of a trusting familiar relationship with the clinician, lack of experience, and lack of confidence in managing illness. Parents may be concerned that if antibiotics were not prescribed, their child would deteriorate and they may not want to take this risk (Brookes-Howell et al 2014).The need for reassurance resulted in seeking a clinician's advice (Al-Dossari 2013, Alkhaldi et al 2015, Brookes-Howell et al 2013, Chinnasami et al 2016, Ecker et al 2013, Finkelstein et al 2013, Panagakou et al 2011, Rousounidis et al 2011, Vaz et al 2015, Zyoud et al 2015) and if the consultation outcome was a prescription of antibiotics, this reinforced the perceived need for antibiotics in the future (Alili-Idrizi et al 2014, Cabral et al 2016, Rousoundis et al 2011). Parental anxiety was linked to a strong protective instinct towards their child's health and it was repeatedly expressed that if they believed their child needed something they would do whatever was necessary to obtain it (Finkelstein et al 2013). Parents' attitudes to management of childhood infection, use of antibiotics and awareness of antibiotic resistance 
were influenced by the concept of a safety net being required. This was expressed as clinicians being fallible and parents' needed to remain vigilant and proactive in getting the treatment they believed their child needed. Parents were also concerned about seriousness of possible illness and there was a belief that antibiotics reduced complications (Rousounidis et al 2011).

There was a reluctance to delay seeking clinician advice when the child was symptomatic with a cold or sore throat. They did not like to see the child unwell or in pain and felt antibiotics could help reduce anxiety and worry. It was seen as time saving not to return to the clinician for review should there be no improvement (Al-Dossari 2013). This was particularly important if there were issues with child care provision (Dwibedi et al 2011). Some parents felt that taking time off work to care for an ill child would result in loss of earnings, and therefore sought means to accelerate recovery (Ecker et al 2013, Salazar et al 2013). The review identified parents need more support and reassurance when managing their child's illness to help them make informed decisions. Conversely, two studies found that some parents believed antibiotics were withheld by clinicians due to resource rationing and level of cost (Cabral et al 2016, Finkelstein et al 2013). These studies were conducted in America and UK respectively, which have well-established and resourced healthcare systems, and this view may be due to recent increased global publicity regarding reducing antibiotic usage. However this concept would benefit from further exploration. This suggestion was not replicated in any other studies which included countries with less developed health systems.

The literature identified parents' own confidence and experience of caring for and managing ill health can have a direct influence on their ability to care for their child's health. Generally, older mothers were less likely to seek antibiotics for their children, although in one Peruvian study, grandmothers were found to use antibiotics recommended by pharmacists twice as often as mothers (Ecker et al 2013). It is not clear why this was the case, unless influenced from past experiences when perhaps health care access was not so readily available. However, reasons for parental anxiety were also found to be influenced by the mothers' age. Younger mothers were worried predominantly about symptoms of fever, whilst older mothers were concerned about any altered behaviour in their child (Rousoundis et al 2011). It is likely older mothers rely on past experience to inform their decision making, and the number of children in the family influences this. Parents with only one child may have less experience and confidence in managing illness and be more concerned for their child (Rousoundis et al 2011). Certainly, parents who had previously used antibiotics were more aware about the appropriate usage of antibiotics, perhaps due to advice from a clinician, or through learned experience (Agarwal et al 2015). It was likely that when parents had received antibiotics in the past for similar illness symptoms, they used that experience to inform their current antibiotic decision making. Parents wanted to see their children recover quickly and in some cases if significant signs of improvement were shown, parents discontinued antibiotics, considering them unnecessary (Chan and Tang 2006, Yu et al 2014).

Some parents tried to manage their child's illness at home, using alternative treatments and home remedies. This may be based on previous experiences of successful use, and cultural beliefs (Agarwal et al 2015, Brookes-Howell et al 2013, Cabral et al 2016, Chinnasami et al 2016, Dwibedi et al 2015, Ecker et al 2013, Finkelstein et al 2013, Panagakou et al 2011). Sometimes parents preferred to seek advice from pharmacists and commenced antibiotics themselves to avoid taking time off work to visit the clinician and consultation costs (Al-Dossari 2013, Dwibedi et al 2015, Yu et al 2014). It is possible, antibiotics were viewed as a cost effective way to care for children, without paying for clinician time or buying expensive alternative medications (Alkhadi et al 
2015).This degree of self-management was dependant on parental personal attitudes and health beliefs. However, in one study in Hong Kong, parents were found to behave differently towards their child's illness than their own and be more cautious regarding antibiotic use (Wun et al 2012). In this study most parents avoided antibiotics for their child, due to concerns about side effects and viewed their children as more vulnerable due to an immature weaker immune system. However, if the illness was perceived as being serious, antibiotics were sought as they were considered effective and fast acting (Alkhaldi et al 2015, Chinnasami et al 2016, Rousounidis et al 2011).

This review included studies from a range of countries and attitudes, where antibiotic prescribing may be influenced by the cultural, social and healthcare norms of these different countries. Only one study, in Greece, included the attitudes and practices of immigrant parents. This study identified that this client group would be dissatisfied if they did not receive antibiotics, would consider changing their clinician and would be more likely to buy over the counter antibiotics (Rousoundis et al 2011). The study does not identify which countries the immigrants were from in order to identify any cultural influences to their behaviour. However, other studies cited parents would consider changing their clinician if they did not receive antibiotics (Al-Dossari 2013, Farha et al 2016, Panagakou et al 2011, Rousounidis et al 2011, Zyoud et al 2015).

Three studies identified parents followed clinician advice in terms of completing antibiotic courses (Agarwal et al 2015, Brookes-Howell et al 2013, Chan and Tang 2006). Brookes-Howell et al (2013) found parents were motivated to adhere to, and be compliant with medical advice. This was primarily due to the fulfilment of their parental role and responsibilities to care for their child and get them well. This was supported by Ecker et al's (2013) study in Peru, which found although there was a high antibiotic usage in children under five years of age, the vast majority of parents deferred and complied with physician prescribing and actively sought this reassurance rather than self-prescribing.

\section{Review limitations}

The review was limited to articles published in English which met the search inclusion criteria. This may have meant some research was not reviewed, although only one article was identified that was not published in English. The included articles were published in a range of countries, and differences in the provision and arrangements of health care systems between countries may have influenced the study findings. However, the publications reviewed identify common themes in a variety of healthcare settings which attests to the global nature of the issue.

\section{CONCLUSION}

The review identified the main themes that impact on and influence parental expectations to receive antibiotics for their children. One main influence was the concern and the perceived seriousness of their child's illness. Parents relied on the clinician to provide reassurance, advice and information regarding the care of their child; however lack of consultation time and use of complex language impacted on the quality of parents and clinicians relationship. As a result, parents were not reassured and often relied on previous experiences and outcomes that had influenced their expectations.

The literature identified a gap in qualitative studies to explore the knowledge, attitudes and practices of parents. Further high quality research should be undertaken to explore the underlying issues experienced by parents. This will enable parents to gain a deeper understanding of appropriate antibiotic use and where to obtain information, potentially influencing future behaviour. Suitable strategies and interventions need to be developed, to address these 
influences and accessible information provided to parents, so they can make informed decisions regarding their child's health.

\section{Relevance to clinical practice}

Health care professionals need to ensure adequate time is provided to parents, for explanations of decision making and reassurance. Easy to read information regarding appropriate antibiotic usage should be easily accessible for parents.

\section{Funding}

- This research is funded through PhD sponsorship by Oxford Health NHS Foundation Trust

\section{Conflict of interest}

- There is no conflict of interest

\section{Author contributions}

- All authors contributed to the conceptual development, drafting of paper and critical revisions.

\section{REFERENCES}

Agarwal, S., Yewale, V. N., \& Dharmapalan, D. (2015). Antibiotics Use and Misuse in Children: A Knowledge, Attitude and Practice Survey of Parents in India. Journal of Clinical and Diagnostic Research : JCDR, 9(11), SC21-SC24

Al-Dossari, K. (2013). Parental Knowledge, Attitude and Practice on Antibiotic Use for Upper Respiratory Tract Infections in Children. Majmaah Journal of Health Sciences (MJHS), 1(1), pp.33-45.

Alili-Idrizi, E., Dauti, M. and Malaj, L. (2014). Validation of the parental knowledge and attitude towards antibiotic usage and resistance among children in Tetovo, the Republic of Macedonia. Pharmacy Practice (Internet), 12(4), pp.0-0.

Alkhaldi, S., Al-Mahmoud, M. and Kanaan, H. (2015). Mothers' Knowledge, Attitudes and Practices of Antibiotic Use for Children in Jordan. Jordan Medical Journal, 49(4), pp.215-226.

Annual Report of the Chief Medical Officer, Volume Two, 2011, Infections and the rise of antimicrobial resistance. Department of Health, 2011. London (Published March 2013).

Aveyard, H. (2014). Doing literature review in health and social care. 1st ed. Maidenhead: McGraw-Hill/Open University Press.

Booth, A., Sutton, A. and Papaioannou, D. (2016). Systematic approaches to a successful literature review. 1st ed. Los Angeles: SAGE.

Braun, V. and Clarke, V. (2006). Using thematic analysis in psychology. Qualitative Research in Psychology, 3(2), pp.77-101.Department of Health (2013): UK 5 year Antimicrobial Resistance Strategy 2013-2018. London. 
Brookes-Howell, L., Wood, F., Verheij, T., Prout, H., Cooper, L., Hood, K., Melbye, H., Torres, A., Godycki-Cwirko, M., Fernandez-Vandellos, P., Ystgaard, M., Falk Taksdal, T., Krawczyk, J. and Butler, C. (2013). Trust, openness and continuity of care influence acceptance of antibiotics for children with respiratory tract infections: a four country qualitative study. Family Practice, 31(1), pp.102-110.

Cabral, C., Ingram, J., Lucas, P., Redmond, N., Kai, J., Hay, A. and Horwood, J. (2016). Influence of Clinical Communication on Parents Antibiotic Expectations for Children with Respiratory Tract Infections. The Annals of Family Medicine, 14(2), pp.141-147.

Chan, G.C. and Tang, S.F. (2006) Parental knowledge, attitudes and anti-biotic use for acute upper respiratory tract infection in children attending a primary healthcare clinic in Malaysia. Singapore Medical Journal, 47, 266-270.

Chinnasami, B., Sadasivam, K., Ramraj, B. and Pasupathy, S. (2016). Knowledge, attitude and practice of parents towards antibiotic usage and its resistance. International Journal of Contemporary Pediatrics, pp.256-261.

Department of Health (2013): UK 5 year Antimicrobial Resistance Strategy 2013-2018. London.

Davies, J. and Davies, D. (2010). Origins and Evolution of Antibiotic Resistance. Microbiology and Molecular Biology Reviews, 74(3), pp.417-433.

Dwibedi, N., Sansgiry, S., Johnson, M., Abughosh, S., Essien, E. and Mehta, P. (2015). Parents' Expectations to Receive Antibiotic Prescriptions for Children. Journal of Human Behavior in the Social Environment, 25(6), pp.530-551.

Ecker, L., Ochoa, T., Vargas, M., Del Valle, L. and Ruiz, J. (2013). Factors Affecting Caregivers' Use of Antibiotics Available Without a Prescription in Peru. PEDIATRICS, 131(6), pp.e1771e1779.

Farha, R., Suyagh, M., Alsakran, L., Alsous, M. and Alefishat, E. (2016). Parental views of antibiotic use in children with upper respiratory tract infections in Jordan. Tropical Journal of Pharmaceutical Research, 15(9), p.2009.

Finkelstein, J., Dutta-Linn, M., Meyer, R. and Goldman, R. (2013). Childhood Infections, Antibiotics, and Resistance: What Are Parents Saying Now?. Clinical Pediatrics, 53(2), pp.145150.

HM Government (2016). Review on Antimicrobial Resistance: tackling drug-resistant infections globally. London.

https://amrreview.org/sites/default/files/160525 Final\%20paper with\%20cover.pdf https://www.gov.uk/government/uploads/system/uploads/attachment data/file/477962/ES PAUR Report 2015.pdf

Johnstone, M.-J. (2016), Editorial: The moral significance of antimicrobial resistance and the rise of 'apocalyptic superbugs'. Journal of Clinical Nursing, 25: 2079-2082. doi: 10.1111/jocn.13350 
Mangione-Smith, R., Elliott, M., Stivers, T., McDonald, L. and Heritage, J. (2006). Ruling Out the Need for Antibiotics. Archives of Pediatrics \& Adolescent Medicine, 160(9).

McNulty, C., Boyle, P., Nichols, T., Clappison, P. and Davey, P. (2007). The public's attitudes to and compliance with antibiotics. Journal of Antimicrobial Chemotherapy, 60(Supplement 1 ), pp. 63-68.

McNulty, C., Nichols, T., French, D., Joshi, P. and Butler, C. (2013). Expectations for consultations and antibiotics for respiratory tract infection in primary care: the RTI clinical iceberg. British Journal of General Practice, 63(612), pp.429-436.

Moher, D., Shamseer, L., Clarke, M., Ghersi, D., Liberati, A., Petticrew, M., Shekelle, P. and Stewart, L. (2015). Preferred reporting items for systematic review and meta-analysis protocols (PRISMA-P) 2015 statement. Systematic Reviews, 4(1), p.1.

Murphy, M., Bradley, C. and Byrne, S. (2012). Antibiotic prescribing in primary care, adherence to guidelines and unnecessary prescribing - an Irish perspective. BMC Family Practice, 13(1) p. 43.

Parliamentary Science and Technology Committee (2014) - First Report of Session: Ensuring access to working antimicrobials. London.

http://www.publications.parliament.uk/pa/cm201415/cmselect/cmsctech/509/50902.htm

Panagakou, S., Spyridis, N., Papaevangelou, V., Theodoridou, K., Goutziana, G., Theodoridou, M., Syrogiannopoulos, G. and Hadjichristodoulou, C. (2011). Antibiotic use for upper respiratory tract infections in children: A cross-sectional survey of knowledge, attitudes, and practices (KAP) of parents in Greece. BMC Pediatrics, 11(1).

Public Health England (2015). English surveillance programme for antimicrobial utilisation and resistance (ESPAUR) 2010 to 2014.London.

Rousounidis, A., Papaevangelou, V., Hadjipanayis, A., Panagakou, S., Theodoridou, M., Syrogiannopoulos, G. and Hadjichristodoulou, C. (2011). Descriptive Study on Parents' Knowledge, Attitudes and Practices on Antibiotic Use and Misuse in Children with Upper Respiratory Tract Infections in Cyprus. International Journal of Environmental Research and Public Health, 8(12), pp.3246-3262.

Sackett, D. (1979). Bias in analytic research. Journal of Chronic Diseases, 32(1-2), pp.51-63.

Salazar, M., English, T. and Eiland, L. (2012). Caregivers' Baseline Understanding and Expectations of Antibiotic Use for Their Children. Clinical Pediatrics, 51(7), pp.632-637.

Salonga, M.J.C., 2009. Beliefs and Practices of Parents on the Use of Antibiotics for Their Children with Upper Respiratory Tract Infection. Pediatric Infectious Disease Society of the Philippines Journal, 10(1), pp.40-44. 
Stivers, T. (2002). Participating in decisions about treatment: overt parent pressure for antibiotic medication in pediatric encounters. Social Science \& Medicine, 54(7), pp.11111130.

Sukkar, E. (2013). Why are there so few antibiotics in the research and development pipeline? The Pharmaceutical Journal, Vol. 291, p.520

Thomas, J., Harden, A., Oakley, A., Oliver, S., Sutcliffe, K.,Rees, R., Brunton, G., and Kavanagh, J. (2004). Integrating qualitative research with trials in systematic reviews. BMJ, 328(7446), pp.1010-1012.

Vaz, L., Kleinman, K., Lakoma, M., Dutta-Linn, M., Nahill, C., Hellinger, J. and Finkelstein, J. (2015). Prevalence of Parental Misconceptions About Antibiotic Use. PEDIATRICS, 136(2), pp.221-231.

World Health Organisation (2016) Antibiotic resistance fact sheet No.194 http://www.who.int/mediacentre/factsheets/fs194/en/ accessed 18/02/17

Wun, Y., Lam, T., Lam, K. and Sun, K. (2012). Antibiotic use: do parents act differently for their children? International Journal of Clinical Practice, 66(12), pp.1197-1203.

Yu, M., Zhao, G., Stålsby Lundborg, C., Zhu, Y., Zhao, Q. and Xu, B. (2014). Knowledge, attitudes, and practices of parents in rural China on the use of antibiotics in children: a crosssectional study. BMC Infect Dis, 14(1).

Zyoud, S., Abu Taha, A., Araj, K., Abahri, I., Sawalha, A., Sweileh, W., Awang, R. and Al-Jabi, S. (2015). Parental knowledge, attitudes and practices regarding antibiotic use for acute upper respiratory tract infections in children: a cross-sectional study in Palestine. BMC Pediatrics, 15(1)

Word Count: 6427 excluding abstract, references and tables 
Table 1: Flow diagram outlining the number of articles screened for inclusion in the systematic review

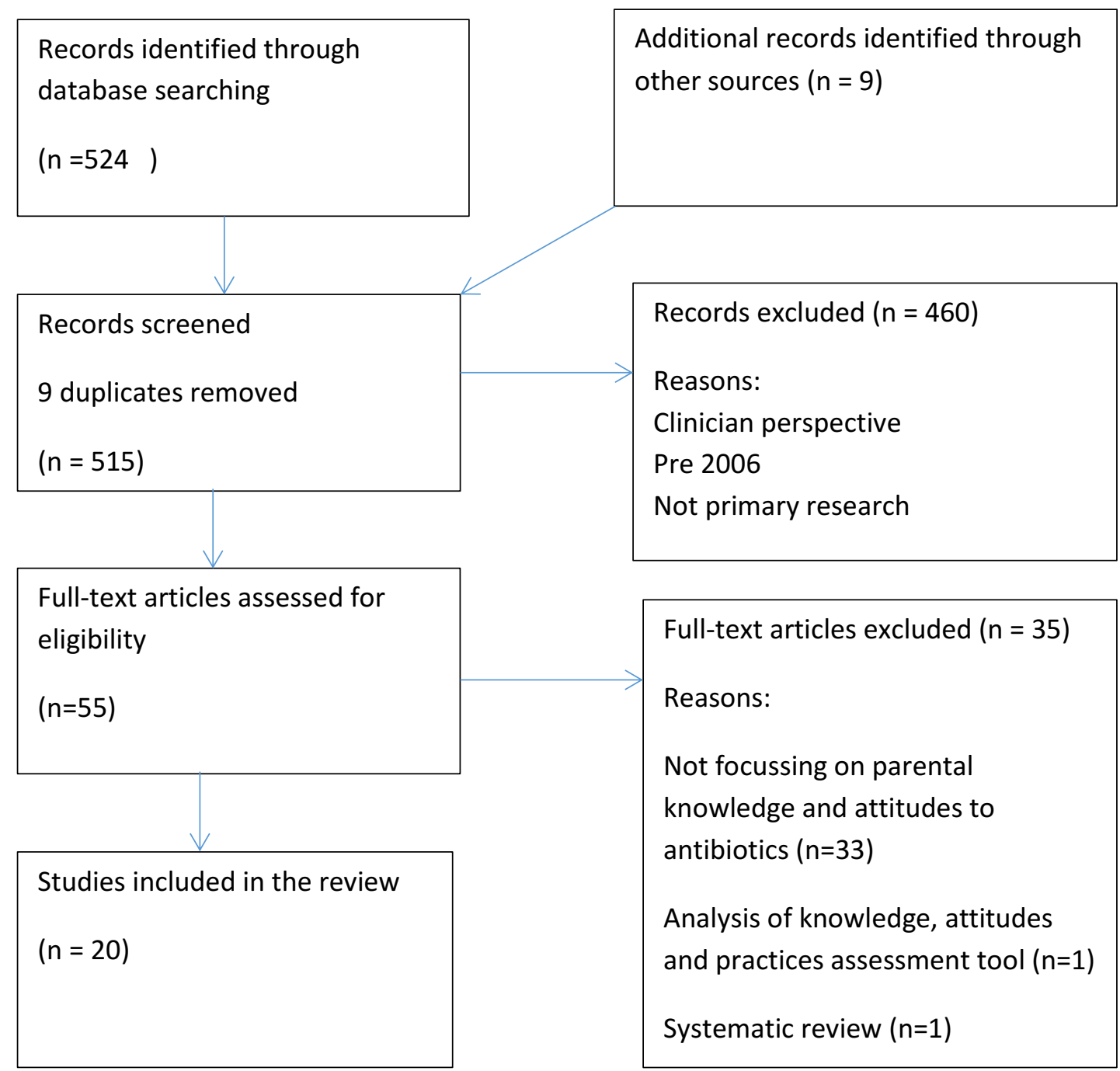

Table 2: Summary characteristics of studies - Table of evidence 


\begin{tabular}{|c|c|c|c|c|c|c|c|}
\hline & $\begin{array}{l}\text { Author/s } \\
\text { Year }\end{array}$ & Country & Study Aim & $\begin{array}{l}\text { Setting and } \\
\text { participants }\end{array}$ & $\begin{array}{l}\text { Study Design } \\
\text { Methods }\end{array}$ & Key Findings & Study Limitations \\
\hline 1 & $\begin{array}{l}\text { Agarwal, S., et } \\
\text { al (2015). }\end{array}$ & India & $\begin{array}{l}\text { Analyse the knowledge, } \\
\text { attitude and practices } \\
\text { of antibiotic use among } \\
\text { parents and correlate it } \\
\text { with the gender, } \\
\text { education level and } \\
\text { previous use of } \\
\text { antibiotics by the } \\
\text { parents. }\end{array}$ & $\begin{array}{l}872 \text { parents in } \\
\text { Paediatric OPD } \\
\text { hospital clinic }\end{array}$ & $\begin{array}{l}\text { Quantitative } \\
\text { Cross-sectional } \\
\text { questionnaire }\end{array}$ & $\begin{array}{l}\text { Lack of knowledge } \\
\text { and misconceptions } \\
\text { about use of } \\
\text { antibiotics } \\
\text { Generally aware of } \\
\text { risks of overuse }\end{array}$ & $\begin{array}{l}\text { Only } 1 \text { hospital so } \\
\text { cannot generalise } \\
\text { results } \\
\text { Set in urban area so } \\
\text { populations may be } \\
\text { more literate and } \\
\text { informed re antibiotics }\end{array}$ \\
\hline 2 & $\begin{array}{l}\text { Al-Dossari, K. } \\
\text { (2013). }\end{array}$ & Saudi Arabia & $\begin{array}{l}\text { Assess level of } \\
\text { knowledge and practice } \\
\text { of parents about } \\
\text { antibiotic use for upper } \\
\text { respiratory tract } \\
\text { infection (URTI) and } \\
\text { determine the } \\
\text { contributing factors for } \\
\text { inappropriate use. }\end{array}$ & $\begin{array}{l}353 \text { parents in } \\
2 \text { primary } \\
\text { healthcare } \\
\text { centres }\end{array}$ & $\begin{array}{l}\text { Quantitative } \\
\text { Cross-sectional } \\
\text { questionnaire }\end{array}$ & $\begin{array}{l}\text { Weather changes } \\
\text { believed to be main } \\
\text { cause of URTI. Felt } \\
\text { antibiotics could help } \\
\text { ease anxiety and } \\
\text { worry if child had } \\
\text { them and they would } \\
\text { not need to return in } \\
\text { a few days if no } \\
\text { improvement }\end{array}$ & $\begin{array}{l}\text { Language and phrasing } \\
\text { used in questions may } \\
\text { not be fully understood } \\
\text { by parents of low } \\
\text { socioeconomic status } \\
\text { (due to medical terms) } \\
\text { leading to inaccurate } \\
\text { answers. } \\
\text { Poor recall of URTI } \\
\text { experience and } \\
\text { antibiotic use }\end{array}$ \\
\hline 3 & $\begin{array}{l}\text { Alili-Idrizi E, et } \\
\text { al (2014) }\end{array}$ & Macedonia & $\begin{array}{l}\text { Explore the knowledge } \\
\text { and attitudes of parents } \\
\text { on the use of antibiotics } \\
\text { among children that } \\
\text { could serve as baseline } \\
\text { data and provide } \\
\text { further insight in } \\
\text { planning and } \\
\text { developing strategies } \\
\text { for local health } \\
\text { education purposes. }\end{array}$ & $\begin{array}{l}500 \text { parents } \\
\text { presenting } \\
\text { with } \\
\text { antibiotics } \\
\text { prescriptions } \\
\text { at } 6 \\
\text { community } \\
\text { pharmacies }\end{array}$ & $\begin{array}{l}\text { Quantitative } \\
\text { Cross-sectional } \\
\text { questionnaire }\end{array}$ & $\begin{array}{l}\text { Confusion among } \\
\text { parents about the } \\
\text { effectiveness of } \\
\text { antibiotics for } \\
\text { bacterial or viral } \\
\text { infections. } \\
\text { Parents expected } \\
\text { antibiotics to speed } \\
\text { up the recovery of } \\
\text { their children from } \\
\text { the common cold }\end{array}$ & $\begin{array}{l}\text { Self-administered } \\
\text { questionnaires increase } \\
\text { the precision of } \\
\text { responses obtained. } \\
\text { Data provided is of local } \\
\text { interest }\end{array}$ \\
\hline 4 & $\begin{array}{l}\text { Alkhaldi, S., et } \\
\text { al (2015). }\end{array}$ & Jordan & $\begin{array}{l}\text { Factors that influence } \\
\text { knowledge, attitudes } \\
\text { and practices related to } \\
\text { antibiotic use among } \\
\text { mothers of children } \\
\text { with URTI }\end{array}$ & $\begin{array}{l}401 \text { mothers } \\
\text { from } 2 \\
\text { primary health } \\
\text { centres }\end{array}$ & $\begin{array}{l}\text { Quantitative } \\
\text { Cross-sectional } \\
\text { questionnaire }\end{array}$ & $\begin{array}{l}\text { Lack of basic } \\
\text { knowledge } \\
\text { Poor attitude towards } \\
\text { antibiotics }\end{array}$ & Only 2 areas sampled \\
\hline 5 & $\begin{array}{l}\text { Brookes- } \\
\text { Howell, L., et } \\
\text { al (2013). }\end{array}$ & UK & $\begin{array}{l}\text { To achieve deeper } \\
\text { understanding parents } \\
\text { acceptance of } \\
\text { otherwise of clinicians } \\
\text { prescribing decisions } \\
\text { for children with RTI }\end{array}$ & $\begin{array}{l}63 \text { parents } \\
\text { across } 4 \\
\text { countries- } \\
\text { Norway, } \\
\text { Poland, Spain, } \\
\text { Wales in } \\
\text { primary care } \\
\text { settings }\end{array}$ & $\begin{array}{l}\text { Qualitative } \\
\text { Interviews }\end{array}$ & $\begin{array}{l}\text { Open communication } \\
\text { and trust important in } \\
\text { acceptance of } \\
\text { management }\end{array}$ & $\begin{array}{l}\text { Overall sample was } \\
\text { large for qualitative } \\
\text { study, interviewed } \\
\text { numbers relatively } \\
\text { small for each network }\end{array}$ \\
\hline 6 & $\begin{array}{l}\text { Cabral, C., et } \\
\text { al (2016). }\end{array}$ & UK & $\begin{array}{l}\text { Understand clinician } \\
\text { perceptions of } \\
\text { communication for } \\
\text { URTI and the influence } \\
\text { communication has on } \\
\text { parental understanding }\end{array}$ & $\begin{array}{l}27 \text { parents } \\
13 \text { clinicians in } \\
6 \text { primary care } \\
\text { settings }\end{array}$ & $\begin{array}{l}\text { Qualitative } \\
\text { Semi structured } \\
\text { video } \\
\text { elicitation } \\
\text { interviews }\end{array}$ & $\begin{array}{l}\text { Previous antibiotic } \\
\text { prescriptions } \\
\text { reinforce beliefs that } \\
\text { similar recurring } \\
\text { symptoms require } \\
\text { same treatment. }\end{array}$ & $\begin{array}{l}\text { First time video } \\
\text { elicitation interviews } \\
\text { used- but recording } \\
\text { may have influenced } \\
\text { behaviour. } \\
\text { Limited geographical }\end{array}$ \\
\hline
\end{tabular}




\begin{tabular}{|c|c|c|c|c|c|c|c|}
\hline & & & of antibiotics treatment & & & $\begin{array}{l}\text { Clinicians prescribing } \\
\text { behaviour and } \\
\text { parents beliefs } \\
\text { influence each other }\end{array}$ & $\begin{array}{l}\text { area so not able to } \\
\text { generalise }\end{array}$ \\
\hline 7 & $\begin{array}{l}\text { Chan, G.C. } \\
\text { and Tang, S.F. } \\
(2006)\end{array}$ & Malaysia & $\begin{array}{l}\text { Assess the parental } \\
\text { knowledge, attitudes } \\
\text { and antibiotic use for } \\
\text { common childhood } \\
\text { acute upper respiratory } \\
\text { tract infection } \\
\text { (URTI) }\end{array}$ & $\begin{array}{l}421 \text { parents in } \\
\text { primary health } \\
\text { clinic }\end{array}$ & $\begin{array}{l}\text { Quantitative } \\
\text { Cross-sectional } \\
\text { questionnaire }\end{array}$ & $\begin{array}{l}\text { Poor parental } \\
\text { knowledge on } \\
\text { antibiotic use } \\
\text { Weather changes } \\
\text { believed to be main } \\
\text { cause URTI }\end{array}$ & $\begin{array}{l}\text { Localised to suburban } \\
\text { population so not } \\
\text { generalizable to whole } \\
\text { population } \\
\text { Study relied on self- } \\
\text { reporting }\end{array}$ \\
\hline 8 & $\begin{array}{l}\text { Chinnasami, } \\
\text { B., et al } \\
(2016) \text {. }\end{array}$ & India & $\begin{array}{l}\text { Assess the knowledge, } \\
\text { attitude and practices } \\
\text { (KAP) about rational } \\
\text { antibiotic usage and } \\
\text { antibiotic resistance } \\
\text { among parents }\end{array}$ & $\begin{array}{l}491 \text { parents } \\
\text { Paediatric OPD } \\
\text { hospital clinic }\end{array}$ & $\begin{array}{l}\text { Quantitative } \\
\text { Cross-sectional } \\
\text { questionnaire }\end{array}$ & $\begin{array}{l}\text { Level of trust in } \mathrm{Dr} \\
\text { influences knowledge } \\
\text { and attitudes } \\
\text { Poor general } \\
\text { knowledge especially } \\
\text { of differences } \\
\text { between bacteria } \\
\text { and viruses }\end{array}$ & $\begin{array}{l}\text { Parents of sick children } \\
\text { attending OPD may } \\
\text { have higher trust } \\
\text { towards Dr influencing } \\
\text { results }\end{array}$ \\
\hline 9 & $\begin{array}{l}\text { Dwibedi, N., } \\
\text { et al (2015). }\end{array}$ & USA & $\begin{array}{l}\text { Evaluate whether } \\
\text { parental expectations } \\
\text { would change after } \\
\text { manipulating their } \\
\text { perceived barriers to } \\
\text { visit Dr's without any } \\
\text { expectation for } \\
\text { antibiotic prescriptions } \\
\text { and their perceived } \\
\text { benefits of using } \\
\text { antibiotics }\end{array}$ & $\begin{array}{l}300 \text { surveys in } \\
\text { primary care } \\
\text { settings }\end{array}$ & $\begin{array}{l}\text { Quantitative } \\
\text { Prospective } \\
\text { experimental }\end{array}$ & $\begin{array}{l}\text { Perceived barriers did } \\
\text { affect expectation } \\
\text { scores }\end{array}$ & $\begin{array}{l}\text { Did not discuss } \\
\text { whether or how the } \\
\text { findings can be } \\
\text { transferred to other } \\
\text { populations }\end{array}$ \\
\hline 10 & $\begin{array}{l}\text { Ecker, L., et al } \\
\text { (2013). }\end{array}$ & Peru. & $\begin{array}{l}\text { Determine factors that } \\
\text { affect caregivers' } \\
\text { decisions about } \\
\text { antibiotic use in } \\
\text { children in settings } \\
\text { where antibiotics are } \\
\text { available without } \\
\text { prescription }\end{array}$ & $\begin{array}{l}1200 \text { surveys } \\
\text { in } 3 \text { periurban } \\
\text { districts of } \\
\text { Lima }\end{array}$ & $\begin{array}{l}\text { Quantitative } \\
\text { Cross-sectional } \\
\text { questionnaires }\end{array}$ & $\begin{array}{l}\text { Caregivers usually } \\
\text { comply with clinicians } \\
\text { advice }\end{array}$ & $\begin{array}{l}\text { Self-reported } \\
\text { information on events } \\
\text { that had taken place } \\
\text { during a child's life, } \\
\text { recall bias may have } \\
\text { influenced results. }\end{array}$ \\
\hline 11 & $\begin{array}{l}\text { Farha, R., et al } \\
\text { (2016). }\end{array}$ & Jordan & $\begin{array}{l}\text { Assess the knowledge, } \\
\text { attitudes and practices } \\
\text { of parents towards } \\
\text { antibiotic use for upper } \\
\text { respiratory tract } \\
\text { infections (URTIs) in } \\
\text { Jordan }\end{array}$ & $\begin{array}{l}10 \text { private } \\
\text { clinics } \\
1329 \text { parents }\end{array}$ & $\begin{array}{l}\text { Quantitative } \\
\text { Cross-sectional } \\
\text { questionnaires }\end{array}$ & $\begin{array}{l}\text { Lack of knowledge in } \\
\text { use and misuse of } \\
\text { antibiotics }\end{array}$ & $\begin{array}{l}\text { Relied on self-rated } \\
\text { assessment }\end{array}$ \\
\hline 12 & $\begin{array}{l}\text { Finkelstein, } \\
\text { J.et al (2013). }\end{array}$ & USA & $\begin{array}{l}\text { Explore the knowledge } \\
\text { and attitudes } \\
\text { surrounding common } \\
\text { infections and antibiotic } \\
\text { use in current era of } \\
\text { more judicious } \\
\text { prescribing }\end{array}$ & $\begin{array}{l}31 \text { parents } \\
4 \text { paediatric } \\
\text { practices } \\
\text { ( } 3 \text { urban and } 1 \\
\text { suburban) in } 2 \\
\text { health systems } \\
\text { in } \\
\text { Massachusetts }\end{array}$ & $\begin{array}{l}\text { Qualitative } \\
5 \text { Focus groups }\end{array}$ & $\begin{array}{l}\text { Parents were } \\
\text { generally } \\
\text { knowledgeable. } \\
\text { Decision to prescribe } \\
\text { antibiotics is end } \\
\text { result of complex } \\
\text { interplay of care } \\
\text { seeking by parents, } \\
\text { and a process of } \\
\text { shared decision } \\
\text { making with doctor }\end{array}$ & $\begin{array}{l}\text { Limited area for study } \\
\text { Dominant individual } \\
\text { emerged as } \\
\text { knowledgeable unclear } \\
\text { whether this } \\
\text { influenced expression } \\
\text { of misconceptions or } \\
\text { alternative views held } \\
\text { by the others }\end{array}$ \\
\hline
\end{tabular}




\begin{tabular}{|c|c|c|c|c|c|c|c|}
\hline 13 & $\begin{array}{l}\text { Panagakou, } \\
\text { S., et al } \\
\text { (2011). }\end{array}$ & Greece & $\begin{array}{l}\text { Document and analyse } \\
\text { parental beliefs on } \\
\text { antibiotic use for } \\
\text { children with URTI in } \\
\text { Greece, a country with } \\
\text { high levels of antibiotic } \\
\text { use and resistance }\end{array}$ & $\begin{array}{l}5312 \text { parents } \\
\text { School based } \\
\text { stratified } \\
\text { geographical } \\
\text { clustering } \\
\text { sampling over } \\
\text { all } \\
\text { geographical } \\
\text { areas of } \\
\text { Greece }\end{array}$ & $\begin{array}{l}\text { Quantitative } \\
\text { Questionnaires }\end{array}$ & $\begin{array}{l}\text { Parents and Dr's have } \\
\text { trusted relationship } \\
\text { Majority parents } \\
\text { believed URTI were } \\
\text { self-limiting but } \\
\text { significant } 74 \% \text { still } \\
\text { expected antibiotics }\end{array}$ & $\begin{array}{l}\text { Limitations were } \\
\text { associated with poor } \\
\text { recall of an upper } \\
\text { respiratory tract } \\
\text { infections (URTI) } \\
\text { experience and } \\
\text { antibiotic use } \\
\text { Knowledge, Attitudes } \\
\text { and practices may not } \\
\text { always be consistent } \\
\text { with actual behaviour - } \\
\text { invalid answers may } \\
\text { have occurred due to } \\
\text { embarrassment }\end{array}$ \\
\hline 14 & $\begin{array}{l}\text { Rousounidis, } \\
\text { A., et al } \\
\text { (2011). }\end{array}$ & Cyprus & $\begin{array}{l}\text { Explore parents and } \\
\text { clinicians KAP } \\
\text { concerning antibiotics } \\
\text { on children 4-7 years } \\
\text { old, with URTI's in } \\
\text { Cyprus }\end{array}$ & $\begin{array}{l}1462 \text { parents } \\
\text { recruited } \\
\text { through } \\
\text { schools }\end{array}$ & $\begin{array}{l}\text { Quantitative } \\
\text { Questionnaires }\end{array}$ & $\begin{array}{l}\text { Parents overall have } \\
\text { trusting relationship } \\
\text { with Dr, who is major } \\
\text { source of information } \\
\text { Immigrant parents } \\
\text { would be unsatisfied } \\
\text { if not given antibiotics } \\
\text { and would change } \\
\text { their Dr and be more } \\
\text { likely to buy over the } \\
\text { counter. }\end{array}$ & $\begin{array}{l}\text { Local interest data } \\
\text { Response rate }<70 \% \\
\text { considered low but self- } \\
\text { answered } \\
\text { questionnaires could } \\
\text { increase honesty of } \\
\text { data }\end{array}$ \\
\hline 15 & $\begin{array}{l}\text { Salazar, M., et } \\
\text { al. (2012) }\end{array}$ & USA & $\begin{array}{l}\text { Evaluate caregivers' } \\
\text { understanding of } \\
\text { antibiotic use for their } \\
\text { children and identified } \\
\text { demographic } \\
\text { characteristics that may } \\
\text { contribute to } \\
\text { inappropriate antibiotic } \\
\text { seeking behaviour }\end{array}$ & $\begin{array}{l}246 \text { care } \\
\text { givers, } 1 \\
\text { academic } \\
\text { paediatric } \\
\text { clinic and } 2 \\
\text { private } \\
\text { paediatric } \\
\text { clinics }\end{array}$ & $\begin{array}{l}\text { Quantitative } \\
\text { Cross-sectional } \\
\text { survey }\end{array}$ & $\begin{array}{l}\text { Demographic } \\
\text { characteristics } \\
\text { influence over } \\
\text { expectations } \\
\text { Caregivers with } \\
\text { higher annual income } \\
\text { and parents with } \\
\text { private insurance } \\
\text { tended not to expect } \\
\text { antibiotics }\end{array}$ & $\begin{array}{l}\text { Survey conducted } \\
\text { locally and } \\
\text { understanding of } \\
\text { antibiotic use could } \\
\text { vary in various parts of } \\
\text { country }\end{array}$ \\
\hline 16 & $\begin{array}{l}\text { Salonga } \\
\text { Micheline } \\
\text { Joyce C. } \\
\text { (2009) }\end{array}$ & Philippines & $\begin{array}{l}\text { Describe the beliefs and } \\
\text { practice of parents on } \\
\text { the use of antibiotics in } \\
\text { the treatment of URTI } \\
\text { in their children }\end{array}$ & $\begin{array}{l}96 \text { parents } \\
\text { over } 1 \text { week } \\
\text { Local health } \\
\text { centre }\end{array}$ & $\begin{array}{l}\text { Quantitative } \\
\text { Cross-sectional } \\
\text { survey }\end{array}$ & $\begin{array}{l}\text { Beliefs influenced by } \\
\text { level of education- } \\
\text { lower more } \\
\text { misconceptions. } \\
\text { Exception self- } \\
\text { prescribing more } \\
\text { likely in more } \\
\text { educated }\end{array}$ & $\begin{array}{l}\text { No analysis as } \\
\text { descriptive data only }\end{array}$ \\
\hline 17 & $\begin{array}{l}\text { Vaz, L., et al } \\
\text { (2015) }\end{array}$ & USA & $\begin{array}{l}\text { Examine current } \\
\text { knowledge and } \\
\text { attitudes about } \\
\text { antibiotic use among } \\
\text { parents of young } \\
\text { children from diverse } \\
\text { socioeconomic } \\
\text { backgrounds, assess } \\
\text { predicators of } \\
\text { particular } \\
\text { misconceptions, and } \\
\text { compare current } \\
\text { knowledge and } \\
\text { attitudes with those }\end{array}$ & $\begin{array}{l}1500 \text { parents- } \\
\text { randomly } \\
\text { selected from } \\
\text { registered } \\
\text { health plans }\end{array}$ & $\begin{array}{l}\text { Quantitative } \\
\text { Survey }\end{array}$ & $\begin{array}{l}\text { Younger parental age, } \\
\text { minority race or } \\
\text { ethnicity and having } \\
\text { less than a college } \\
\text { degree were } \\
\text { important predictors } \\
\text { of less knowledge } \\
\text { regarding antibiotic } \\
\text { use in childhood } \\
\text { illnesses }\end{array}$ & $\begin{array}{l}\text { Respondents not } \\
\text { nationally } \\
\text { representative- } \\
\text { response rates similar } \\
\text { to those seen in other } \\
\text { studies, the results may } \\
\text { not be representative } \\
\text { Survey conducted in } \\
\text { written English within } \\
\text { multilingual } \\
\text { population, biases in } \\
\text { who responded to } \\
\text { survey may have } \\
\text { resulted }\end{array}$ \\
\hline
\end{tabular}




\begin{tabular}{|c|c|c|c|c|c|c|c|}
\hline & & & $\begin{array}{l}\text { found in a similar } \\
\text { survey conducted in } \\
2000\end{array}$ & & & & \\
\hline 18 & $\begin{array}{l}\text { Wun, Y., et al } \\
\text { (2012). }\end{array}$ & Hong Kong & $\begin{array}{l}\text { Explore differences } \\
\text { between parents' use } \\
\text { of antibiotics for } \\
\text { themselves and for } \\
\text { their children }\end{array}$ & $\begin{array}{l}\text { Hong Kong } \\
8 \text { focus } \\
\text { groups- total } \\
56 \text { participants } \\
\text { age } 20-73 \\
\text { years } \\
\text { Parents } \\
\text { included in } \\
\text { larger survey } \\
\text { of general } \\
\text { population }\end{array}$ & $\begin{array}{l}\text { Mixed methods } \\
\text { Quantitative } \\
\text { telephone } \\
\text { survey and } \\
\text { qualitative } \\
\text { focus groups }\end{array}$ & $\begin{array}{l}\text { Parents more } \\
\text { cautious re antibiotics } \\
\text { in their children } \\
\text { Influenced by their } \\
\text { own KAP }\end{array}$ & $\begin{array}{l}\text { Large data set but } \\
\text { unclear on } \\
\text { methodology of } \\
\text { analysis and rationale }\end{array}$ \\
\hline 19 & $\begin{array}{l}\text { Yu Miao, et al } \\
\text { (2014) }\end{array}$ & China & $\begin{array}{l}\text { Investigate parents' } \\
\text { perceptions of } \\
\text { antibiotic use for } \\
\text { children, interactions } \\
\text { between parents and } \\
\text { physicians regarding } \\
\text { treatment with } \\
\text { antibiotics and factors } \\
\text { associated with } \\
\text { parents' self-medicating } \\
\text { with antibiotics. }\end{array}$ & $\begin{array}{l}854 \text { parents in } \\
2 \text { rural } \\
\text { counties in } \\
\text { vaccination } \\
\text { clinics }\end{array}$ & $\begin{array}{l}\text { Quantitative } \\
\text { Cross-sectional } \\
\text { design }\end{array}$ & $\begin{array}{l}\text { Insufficient } \\
\text { knowledge especially } \\
\text { rural areas } \\
\text { Self-medication due } \\
\text { to ease of access to } \\
\text { antibiotics }\end{array}$ & $\begin{array}{l}\text { May not be } \\
\text { representative of } \\
\text { average parents due to } \\
\text { vaccination clinic and } \\
\text { young parents }\end{array}$ \\
\hline 20 & $\begin{array}{l}\text { Zyoud, S., et } \\
\text { al (2015). }\end{array}$ & Palestine & $\begin{array}{l}\text { Examine parents' } \\
\text { knowledge, attitudes } \\
\text { and practices (KAP) } \\
\text { about antibiotic use for } \\
\text { children with uppers } \\
\text { RTI's in Palestine }\end{array}$ & $\begin{array}{l}385 \text { parents in } \\
4 \text { primary } \\
\text { health care in } \\
\text { Palestine }\end{array}$ & $\begin{array}{l}\text { Quantitative } \\
\text { Cross-sectional } \\
\text { design }\end{array}$ & $\begin{array}{l}\text { Lack of parental } \\
\text { knowledge resulted in } \\
\text { inappropriate } \\
\text { attitudes and } \\
\text { practices } \\
\text { Trusted relationship } \\
\text { between parents and } \\
\text { Dr's and confidence } \\
\text { in information and } \\
\text { prescriptions } \\
\text { provided }\end{array}$ & $\begin{array}{l}\text { Convenience sample } \\
\text { which may not be } \\
\text { representative of } \\
\text { population }\end{array}$ \\
\hline
\end{tabular}


Table 3: Themes identified

\begin{tabular}{|c|c|c|c|c|}
\hline Studies & $\begin{array}{l}\text { Quality of relationships } \\
\text { with health care } \\
\text { providers }\end{array}$ & $\begin{array}{l}\text { Dealing with conflicting } \\
\text { messages }\end{array}$ & $\begin{array}{l}\text { Rationalising the need } \\
\text { for antibiotics }\end{array}$ & $\begin{array}{l}\text { Parental practices } \\
\text { informed by past } \\
\text { experience }\end{array}$ \\
\hline Agarwal, S., et al (2015) & & $\sqrt{ }$ & & $\sqrt{ }$ \\
\hline Al-Dossari, K. (2013) & & $\mathbf{v}$ & $\mathbf{v}$ & $\mathbf{v}$ \\
\hline $\begin{array}{l}\text { Alili-Idrizi, E., et al } \\
\qquad(2014)\end{array}$ & $\mathbf{v}$ & $\mathbf{v}$ & $\mathbf{v}$ & $\mathbf{v}$ \\
\hline Alkhaldi, S., et al (2015) & $\mathbf{v}$ & $\mathbf{v}$ & $\mathbf{v}$ & $\mathbf{v}$ \\
\hline $\begin{array}{c}\text { Brookes-Howell, L., et al } \\
\text { (2013) }\end{array}$ & $\mathbf{v}$ & $\mathbf{v}$ & $\mathbf{v}$ & $\mathbf{V}$ \\
\hline Cabral, C., et al. (2016) & $\mathbf{v}$ & $\mathbf{v}$ & $\mathbf{v}$ & \\
\hline $\begin{array}{l}\text { Chan, G.C. and Tang, } \\
\text { S.F. (2006) }\end{array}$ & $\mathbf{v}$ & $\mathbf{v}$ & $\mathbf{v}$ & $\mathbf{v}$ \\
\hline $\begin{array}{c}\text { Chinnasami, B., et al } \\
\text { (2016) }\end{array}$ & $\mathbf{v}$ & $\mathbf{v}$ & $\mathbf{v}$ & $\mathbf{v}$ \\
\hline Dwibedi, N., et al (2015) & $\mathbf{v}$ & $\mathbf{v}$ & $\mathbf{v}$ & $\mathbf{v}$ \\
\hline Ecker, L., et al (2013) & $\mathbf{v}$ & $\mathbf{v}$ & $\mathbf{v}$ & $\mathbf{v}$ \\
\hline Farha, R., et al (2016) & $\mathbf{v}$ & $\mathbf{v}$ & $\mathbf{v}$ & $\mathbf{v}$ \\
\hline $\begin{array}{c}\text { Finkelstein, J., et al } \\
\text { (2013) }\end{array}$ & $\mathbf{v}$ & $\mathbf{v}$ & $\mathbf{v}$ & $\mathbf{V}$ \\
\hline $\begin{array}{l}\text { Panagakou, S., et al } \\
\text { (2011) }\end{array}$ & $\mathbf{v}$ & $\sqrt{ }$ & $\mathbf{v}$ & $\mathbf{v}$ \\
\hline $\begin{array}{l}\text { Rousounidis, A., et al } \\
\text { (2011) }\end{array}$ & $\mathbf{v}$ & $\sqrt{ }$ & $\mathbf{v}$ & $\mathbf{v}$ \\
\hline Salazar, M., et al (2012) & $\mathbf{v}$ & $\mathbf{v}$ & $\mathbf{v}$ & $\mathbf{v}$ \\
\hline $\begin{array}{c}\text { Salonga Micheline Joyce } \\
\text { C. (2009) }\end{array}$ & & $\sqrt{ }$ & $\mathbf{v}$ & $\mathbf{v}$ \\
\hline Vaz, L. ,et al (2015) & $\mathbf{v}$ & $\sqrt{ }$ & $\mathbf{v}$ & \\
\hline Wun, Y., et al (2012) & & $\mathbf{v}$ & $\mathbf{v}$ & \\
\hline Yu Miao, et al (2014) & & $\mathbf{v}$ & $\mathbf{v}$ & $\mathbf{v}$ \\
\hline Zyoud, S., et al (2015) & & $\mathbf{v}$ & $\mathbf{v}$ & $\mathbf{v}$ \\
\hline
\end{tabular}

